\title{
Determining Sustainable Strategies for Directors of Microfinance Banks in Nigeria Josephine Aruoriwo Diete-Spiff
}

\section{Doi:10.5901/ajis.2014.v3n6p125}

Abstract

This literature review study was to explore information from multiple authors and studies on Determining Sustainable Strategies for Directors of Microfinance Banks in Nigeria in other to indoctrinate management best practices in Microfinance banks. The lack of these management best practices highlighted the uncertainty in the microfinance sector, and the adverse effect. The significance of this study, which is to determine strategic management best practices for directors of microfinance banks in Nigeria could prevent further collapse of the sector. Strategic management best practices could encourage microfinance banks developmental goals to bridge the gap between the poor and the rich by providing funding for the working poor and creating an avenue for financial inclusion of the unbanked in Nigeria.

Keywords: Microfinance Banking Concepts, Sustainability Value, Strategic Management, Uncertainty.

Three regular theories proffer a framework for this literature study that includes the concepts of microfinance banking, sustainability value, and strategic management theory. These theories and concepts form the basis for the study's subject that relates to sustainable strategies for managing microfinance banks. The principles provided by the proponents of these three typical theoretical frameworks enable the study of the subject determining sustainable strategies for MFB directors in Nigeria. The combined context of the concepts, as shown in Figure 1, highlights the requirement of a microfinance director in achieving sustainability.

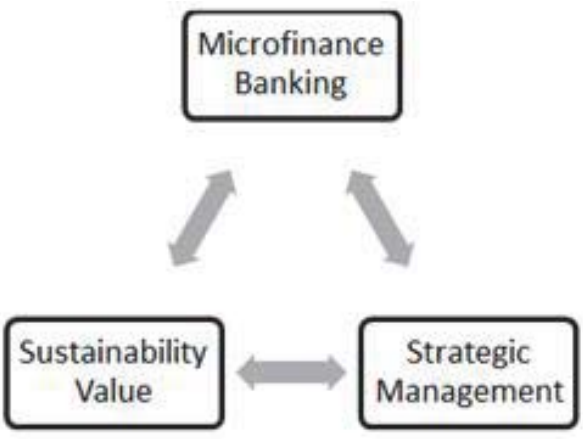

Figure 1. Conceptual framework of the study.

This research review achievement had stemmed from the review of banking record documents, and evaluation of available materials to determine a successful approach to addressing the business concerns of Nigerian MFB institutions. The exploration of multifaceted studies revealed information with a specific interest in strategic management best practices (Abraham \& Balogun, 2012; Bracker, 1980; Conley \& Williams, 2011; Constantinescu, Caescu, \& Ploesteanu, 2012; Idolor \& Eriki, 2012; Johnson \& Arnold, 2012; Marr, 2012; Karlan \& Zinman, 2010; Quinn \& Strategy, 2013; Wellstein \& Kieser, 2011). These articles fashion the structure of this study by revealing understandings of the study's principal themes, identified as microfinance banking, sustainability value, and strategic management required to inculcate management best practices in Microfinance banks. 

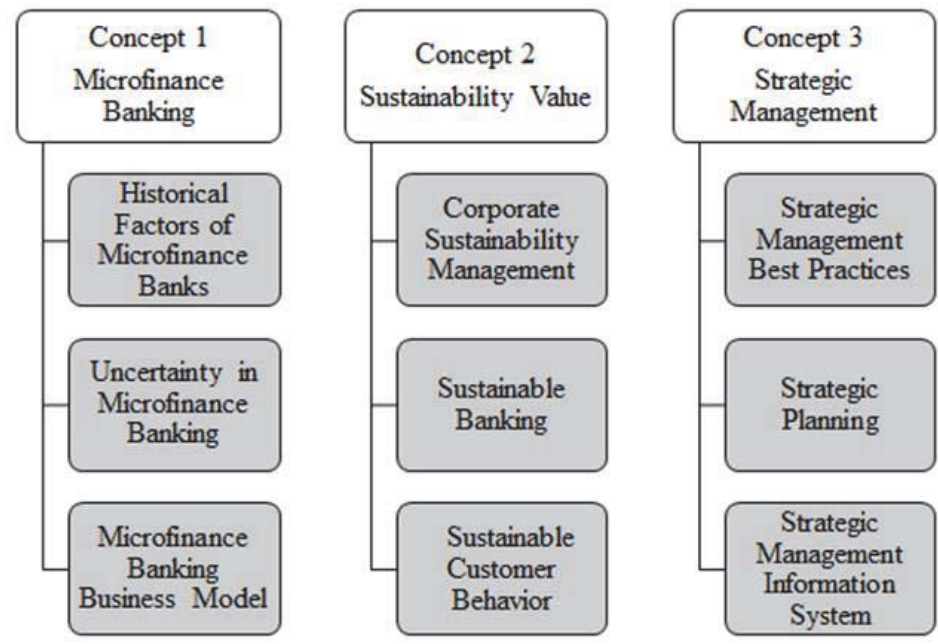

Figure 2. Organization of the literature review by conceptual framework

\section{Microfinance Banking}

Microfinance banking is an instituted concept for the working poor to access funds without collateral. This concept became a global phenomenon that began in Africa, in the 18th century, as evolving credit to the working poor and a nongovernmental scheme to deal with the poor who experience denied admittance to conventional banking (Esty, 2011). The idea of the microfinance bank promoted by Muhammad Yunus of Grameen Bank began in Bangladesh in 1976 as financial inclusion of the working poor (Dixit \& Ghosh, 2013; Yunus, 2003).

\subsection{Historical Factors of Microfinance Banks}

The central bank of Nigeria regulates the banking industry in the country. The banking industry makes up different sectors including commercial banks, development finance institutions, and other finance institution comprised of microfinance banks, finance institutions, bureau de change, discount houses, and primary mortgage institutions (Central Bank of Nigeria, 2011). The use of money for trading had grown through the West African region, but banking started in 1892 with the establishment of the African Banking Corporation in Lagos Nigeria during the monetization of the Nigerian economy from barter trade (Akpala \& Olawuyi, 2013). Despite this development of a strong finance sector, the accessibility to funds by the low-income earners was a problem (Idolor \& Eriki, 2012). This accessibility problem happened because the financial sector is more concerned with the multinational companies and powerful trading firms than the small and medium enterprises, which contributes to $75 \%$ of the labor force of the Nigerian economy (Fishman, 2012).

The concept of microfinance existed before the period of the monetization (Tavanti, 2013). Microfinance lending had different names given in the local language of the people of Nigeria such as Ayo (Yoruba), Akawo (Igbo), and Adashe (Hausa) meaning savings and credit, mainly administered by non-governmental organizations (Ikechukwu, 2012). These methods of microfinance lending changed into more formalized and properly regulated institutions, going through different phases of the name change comprising people's bank, community bank, and now microfinance bank. The institution of MFB was in 2005, recognized by the Nigerian government as a developmental tool to address the disparity in finance administration in the country (Ikechukwu, 2012). The responsibilities of the MFB was to render services to the working poor, in a dual capacity of social mission and financial inclusion, by giving the working poor access to funds (Central Bank of Nigeria, 2011). The attempt to accomplish these dual missions encountered problems in the process because of the lack of sustainable strategies to manage the banking operations (Abraham \& Balogun, 2012).

\subsection{Uncertainty in Microfinance Banking}

Uncertainty besieges microfinance banks in Nigeria because of the directors' inability to control the bank activities and put the customers in the proper banking ethics perspective. The relationship between the customers and the bank became fragile because MFB administration of microloans turned out to be too expensive and the earnings insufficient for the 
institutions to achieve profitability. The uncertainty gets worse as inadequacies in management leads to default in repayment of loans that in turn leads to delinquency, high cost of transactions, and paucities in operations (Kanayo, Jumare, \& Nancy, 2013). This default in loan repayment created a gradual reduction of shareholders' funds, resulting in the closure of the bank offices (Hendrickson \& Nichols, 2011).

Inadequacies in management as evidenced by MFB operations in Nigeria are because of the industry's uncertainty and failure, defeating the essence of the establishments (Florin \& Carmen, 2013). The microfinance bank sector in Nigeria began with high hopes of eradicating poverty, but the misconception as to government support of this sector resulted in problems. The collapse of the sector started with government non-remittance of funds, inadequate funding by the directors and insufficient management expertise to administer available funds (Abraham \& Balogun, 2012). This inadequate management expertise makes operating in the microfinance banks sector difficult and leads to uncertainties. Goel and Hasan (2011) traced the problem of uncertainty to large outstanding debts by the bank's clientele and stressed that MFB's had not mastered the art of monitoring loan facilities advanced to clients.

Supporting this notion, Epstein and Yuthas (2010) attributed large outstanding debt to a culture of non-re-payment. Bhuiyan, Siwar, Ismail, and Talib (2011) argued that the non-repayment was because of inadequate funds in the sector, which caused the release of insufficient funds to the clients. This inadequate funding occurs because of the smallness of the minimum capital for a unit microfinance bank, which is only N20, 000,000 ( $\$ 125,000$ USD) as authorized by the regulatory body CBN (Central Bank of Nigeria, 2011). Assuncao (2013) agreed that the government lacked sufficient financial service distribution network in its policy guidelines to accommodate the MFB inadequacies in funds disbursement. Weill (2011) insisted that the uncertainty in the MFB sector relate to corruption among the management, who channeled funds to clients for personal gains.

Domazet et al. (2011) agreed with Goel and Hasan (2011) in asserting that the uncertainty in the microfinance banks, in Nigeria, was because of deficiencies in the managerial capacity of the directors. These deficiencies made the challenge of business uncertainty in the MFB an issue for serious attention. The consequences of these inadequacies in the director's skill will deprive the growth of microenterprises, education, feeding, and intensify shortage in poor household, which will increase the rate of poverty in Nigeria (Ault \& Spicer, 2013).

\subsection{Microfinance Banking Business Model}

The microfinance banking institution has a banking model that cuts across most nations to serve the working poor. The microfinancing model as popularised by Mohammad Yunus of Grameen Bank in Bangladesh was an adopted model by directors of microfinance banks based on the uniqueness of the environment. The banking model principally stated the modalities for micro lending to the working poor to achieve maximum co-operation and to make repayment easy for the continuation of the lending process (Galariotis, Villa, \& Yusupov, 2011). These micro lending services supported families who originate the small (micro) businesses. These micro businesses provide the essential basis of income, enterprise growth, and employment in the nation, because of the scarcity of salary paid jobs (Dorado, 2013).

\subsubsection{Village banking business model}

The village banking is a community based micro-credit lending scheme instituted by non-governmental organizations to support the working poor and low-income earners. These non-governmental organizations assist village self-help groups by giving credit services and encouraging members to save. These group members are usually the working poor seeking sole proprietorship ventures to sustain the family unit (Bahng, 2013).

The group members function as a bank by managing the affairs of the group, nominating officials, establishing the internal guiding rules, lending to group members, and repaying the loan as stipulated in the guidelines (Jamshidi-Navid \& Arad, 2010). The support for the loans specifies moral uprightness among members instead of collateral. The money for lending originates from member contributions and savings (Taylor, 2011). Fishman (2012) recognized this type of village model microfinancing as practised mainly by women because microfinance banks advance money to women (as opposed to men) for financial and social obligation of the household. Agier (2013) explained the rationale as a microfinance bank strategy to give small loans since that fills the need women have whereas men seek larger amounts of capital. 


\subsubsection{Grameen bank business model}

The Grameen banking model works with group pressure for repayment of granted loan facilities. The bank lends microcredits to small group members as a group guarantee support for the loan instead of tangible collateral. Repayments are made weekly, and group members ensure repayments to retain continuity of the lending process, and this model assessed as effective (Esty, 2011). Korth, Stewart, Rooyen, and De Wet (2012) determined the Grameen microfinance model as harmful and ineffective in the growth of group members as micro entrepreneurs because the high and fast repayment rate provided no opportunity for consolidation of borrowed funds.

\subsubsection{Rotating savings and credit association (ROSCAs) model}

The rotating savings and credit association, also known as a self-help group, is a group whose activities entail the contribution of money, by members, to a single member for a period (Lerpold, 2012). The process of money lending rotates among members, and the goal is to help members invest the money in a project of choice to support the families. Typically, the members of these groups consist of friends and neighbours from the same community with common goals. Fishman (2012) stipulated that the group gatherings enhanced social relationships and productivity, especially among women.

\subsubsection{Mobile banking model}

The mobile money model is a new concept practiced by some microfinance banks that entails the use of innovative technology to lend to low-income earners (Livingston, Glassman, \& Wright, 2011). The objectives were to assist poor working households and to enhance livelihood while protecting the investment of the lending institutions. The procedure of mobile banking specifies the opening of accounts in the market environment of the bank, with specified staff equipped to interview the customers to get to "know your customer" by investigating the person and the persons activities. The process allows customers to acquire an electronic and an ATM card after registration with the bank, both of which provide quick service delivery.

The customer's account approval by the bank will activate the account and the card to allow the customer withdrawals. Das (2013) stated that these mobile banking methods show cost effectiveness, which enables the use of transaction histories and make repayment easy with savings on the cost for the microfinance bank. This mobile banking rationale usage by most microfinance banks is to lower operational expenses, create efficiency, and reduce delinquencies among borrowers. Although, the microfinance institutional models seem laudable, the models are not without defects that will require strategic management to obtain sustainability in dispelling the uncertainty in the sector (Morali \& Searcy, 2013). The microfinance sector needs to advance with the trends in innovative technology to have a competitive advantage and serve the working poor better.

\section{Sustainability Value Concept}

The sustainability value is a substantial approach in this study because sustainability value demonstrates the impact of the relationship between shareholders' value in a business and sustainability as a global business solution challenge. Hart and Milstein (2005) developed the principles of sustainable value to establish the strategies and applications that support a sustainable business in upholding shareholders value. Hart and Milstein named four major potential valuable measures of sustainability strategies in an organization to include pollution prevention, product stewardship, clean technology, and based pyramid. These four measures of sustainability value depicted a reduction in risk, cost of operations, improved character, increased innovative repositioning, and developmental growth chart, which summarizes sustainability management. Sustainability undertakings equally relate to companies financial performance in relationships to direction and development (Kurapatskie \& Darnall, 2013).

\subsection{Corporate sustainability management}

Corporate sustainability indicates the management of sustainable value, which highlights strategic inputs with implementation to position the organization for the challenges of operations and offering dividends to shareholders. Corporate sustainability management survival specifies a balance of performance amid social, environmental, and 
financial synergy (Rahardjo, Idrus, Hadiwidjojo, \& Aisjah, 2013). This system supports the need for sustainable strategies in the microfinance sector to increase rather than decrease shareholder funds. To achieve this, Kearins and Fryer (2013) advocated sustainability value that described the enhancement of the value of a business by the provision of research and development, operating within the business systems to stabilize and salvage resources. In essence, sustainable management is a social change, which signifies development with the proficiency to endure, specifying sustainability value as a value added in an ideal innovative stage of business.

Morali and Searcy (2013) recommended integrated sustainability management technique as an efficient approach to producing progressive triple-bottom-line impacts on the earth, persons, and incomes. Making the existing strategies in the microfinance banking sector require enhancement to achieve flexible sustainability value deliveries in order to obtain market share with creative and competitive advantage (Crittenden et al., 2011). Sustainability, although a goal to accomplish in microfinance business, remains the responsibility of directors, who need to live up to accountabilities because the directors provide hope for the common person (Milliman \& Grosskopf, 2011). Dragan (2012) recommended sustainable strategic management training as a solution to the lack of sustainable management in the microfinance sector of the economy, arguing that the banking management structure should embrace sustainable strategic ethics for better service delivery. Similarly, Conley and Williams (2011) suggested sustainable strategic management teachings in the microfinance sector involving all stakeholders for improved performance.

Likewise, Tiong and Anantharaman (2011) insisted that training enhance sustainability if management and staff were well educated to face the challenges of the job. Skiera, Bermes, and Horn (2011) identified clients' balance sustainability value as an assessment of the client to bank relationship in determining the sustainability of the banks. This balance value necessitated the recommendation of securitization, a significant financial instrument, which allowed the bank to increase profits while encouraging customer loyalty (Mei, Dhaliwal, \& Neamtiu, 2011). The securitization is an approach that promotes immediate repayment of a loan and lowers delinquencies in microfinance banks. Equally, Battilana and Dorado (2010) encouraged organizational participation, in which employees get involved in customer businesses to ensure growth toward sustainability of invested funds.

Conley and Williams (2011), in agreement with this position, specified qualified personnel and dedicated customers as stakeholders of microfinance banks for sustainable strategic banking relations. Sustainable management strategies nurtured in the microfinance-banking sector are the way forward because researchers are optimistic that the challenges, though enormous, remain surmountable. The gathered information from this study tends to prove that bridging the gap in the literature concerning the lack of understanding of strategic management by the directors of microfinance banks could provide solutions to the sectors uncertainty as this research could be a reference tool to the directors of microfinance banks. Microfinance banks stakeholders do need some form of guidelines to harness the desired goal in microfinance banking.

\subsubsection{Sustainable banking}

Sustainable banking started in the primitive era where banks worked as intermediaries between wealthy persons and business owners as a means to better the community (Weber, 2012). Sustainable banking started in the commercial banks with risk management environment and social well-being of the people, giving rise to the importance of banks sorting out methods to effect sustainable growth in developing products and services. Cooperative's and credit unions, which converted into microfinance banks, also developed techniques to serve the market better by instituting principles that formulated the operations in providing products and services associated with sustainability. Typically, governments, companies, associations, professional bodies, and non-government organizations accept the idea of sustainability for economic growth.

\subsubsection{The concept of sustainability in banking}

The concept of sustainability consists of the triple bottom line model, indicating social, economic, and environmental concerns (Elkington, 1997). This concern specifies a business as sustainable, when the company accomplishes high performance levels in social, economic, and environmental issues. The triple bottom line sustainability model enables company stakeholders to evaluate the sustainability performance, and the banking industry is no exception. As in the 19th century, credit unions and financial cooperatives provided small and medium enterprises with financial assistance that laid the foundation for microfinance and deposit money bank lending (Weber, 2012). To lend money with interest, ethical values with the lender's expectation of borrowers' trustworthiness became necessary. 
A borrower must be hard working and responsible for undertaking the risk to succeed. Sustainability on the part of the bank indicates outreach accomplishment, while highlighting the provision of lasting services with available resources. On the premise of inflation and business environment portraying cost, size of the average loan, loan delivery, repayment frequency, salaries, and wages (Fajonyomi, Jegede, \& Akinlabi, 2012). Currently, MFB goals of lending and social mission are to alleviate poverty, which translates to a poor household's ability to earn a living that reduces the dependence on charity (Weber, 2012). The MFB accomplished the remover of the dependence on charity through the administration of microcredit and financial literacy empowerment of the working poor.

Johnson and Arnold (2012) specified that low-income earners were not inclined to the demands of financial facilities like the high-income earners, but for the microfinance banks sustainability and growth, MFB clients must be motivated in strategies of innovation and social support. Environmental sustainability is an endeavor to enhance human wellbeing by the protection of natural resources that can provide manufactured or economic capital (Penzenstadler \& Femmer, 2013).

Das (2013) opined that microfinance bank sustainability would require economic capital, professionalism, divergence, agency services, cost management, interest income, compliance, performance, proficiency, and regular monitoring. Ault and Spicer (2013) specified the need for organizational identity, involving personnel employment, social policies that foster sustainability relating to goals, management principles and a targeting population for the MFB. Olsen (2010) differed from strategic innovation and social impact and advocated more investors in the microfinance sector to ensure sustainability.

Pedrosa and Do (2011) argued that bridging the gap between microfinance banks and poor households would foster sustainability through preventive loan default administration, exhaustive screening of clients in administering loans, and high interest rate. Although, in banking, many have a different opinion of what constitutes sustainability, all agree that literature prevalence on sustainability is more prevalent for commercial banks as compared to MFB. Microfinance banks in Nigeria can adopt the sustainability development and policies of deposit banks by integrating sustainable banking concerns into the strategies, processes, products, and services of the sector. The microfinance banks can achieve this sustainability through a reduction in credit risk, operational risk, and strategic risk by exchanging deprivation with positive social impact.

\subsection{Sustainable customer behavior}

The purpose of researching a sustainable customer behavior model in microfinancing is to understand and maintain positive behavior to assist the working poor to access funds from the MFB. This work will help to understand how customer behavior supports poverty alleviation, achieve the microfinance goals, and become sustainable. In accomplishing a positive customer's behavioral trend, the identity of the MFB customers (the working poor), the financial behavioral characteristics, and the sustainability of microfinance banks as the credit provider needs attention.

\subsubsection{Identification of MFB customers.}

The microfinance operators need to identify the customers they serve in order to provide better service to the right customers. Akpala and Olawuyi (2013) stipulated that the working poor require identification because they are in various categories. These categories Akpala and Olawuyi (2013) defined as the working or active poor include those with unsteady income, the poor, poorest of the poor, the homeless, and the destitute.

The working or active poor constitute the target market for the MFB to train and assist the enterprise aspiring poor to start-up a trade. The working poor identification as low income earners with no access to conventional banking constitute the self-employed, sole proprietors, artisans, street hawkers, pensioners, petty traders, and small-scale farmers (Babandi, 2011). These persons are the most vulnerable with no stable income to maintain a household. Akpala and Olawuyi (2013) argued that the poor needed help irrespective of the category and the government or well-meaning persons should support the poor as a responsibility without requiring repayment.

\subsubsection{The MFB customers' financial behavior}

The working poor financial behavior depends on the income because accomplishing personal objectives needs motivation and activity (McGee, 2012). The incomes from activities help the working poor provide for the household. Klawitter, Anderson, and Gugerty (2013) described the characteristics of the working poor as those with income from 
activities such as petty trading, owner-operated businesses with no financial records, and incomes not separated from family finances. These working poor have no access to credit, but instead work with family or friend loans, self-help groups, and moneylenders as the means to gain financial support. These people attitude show banking-shy and sensitivity to borrowing, but willingly repay loans.

Johnson and Arnold (2012) attributed the challenge faced by these people to a lack of credit to trade resulting in non-sustenance of household and subsequent market exclusion. In support of the poor access to credit, Yunus (2003) stated that poor persons were in the category of creditworthy individuals who can repay loans. The working poor were very enthusiastic about acquiring credit and willing to repay with interest as development was of more importance than the interest payment of loans. Sandberg (2012) posited that the customers were less concerned with interest rates charged by the MFB because the other moneylenders charge a higher rate of interest than the MFB, who in addition, give financial enhancement counseling. To Marr (2012), lack of credit to the poor remains an increasing challenge to success in microenterprises, though microfinancing has moved from an unassertive philanthropic movement into a more professionalized business the poor access to funds remains limited. This increasing challenge to acquiring funds is an indicator that the working poor need access to credit in improving the earnings and invariably increase the economy of a nation.

\subsubsection{MFB as sustainable credit provider}

The sustenance of MFB as a credit provider is an important venture because MFB provides social assistance and financial earnings to the customers (Ault \& Spicer, 2013). This provision of social assistance and financial earnings is in support of the assertion that MFB is a developmental tool for sustainability and social intermediation. Similarly, Germaise and Natividad (2013) described MFB as lending institutions founded on emerging markets that support poor customers with credit and business information. This description of the MFB as a provider of credit and business information affirms the understanding of MFB goals of assisting the working poor to save, access basic needs, and provision of insurance against unexpected circumstances. MFB criticism dwells in the failure to give credit to the poorest of the poor who require more support to fight poverty in agreement with the MFB social mandate (Priyadarshee, Hossain, \& Arun, 2010).

Conley and Williams (2011) argued against the notion of giving credit to the non-working poor as philanthropic gestures that were not banking policies or sustainable banking practices, which increases risk exposure. The emphasis on the MFB sustainability as a credit provider is the sensitivity to the clients, access to funds, sustainable strategic management information, and capacity to assist in building up the poor's trade (Roberts, 2013). The establishment and existence of MFB influence the working poor behavioral pattern because the MFB makes credit accessible to the working poor that improves the household.

MFB's should identify the customers, understand the financial behavior, and sustain the customers' access to credit. These attributes if exhibited by the MFB will empower the working poor and the growth of the Nigerian economy because the poor constitute a greater percentage of the populace.

\section{Strategic Management}

Strategic management describes the processes required to achieve an organizational need for growth and the activities required to proceed positively toward achieving these needs in a sustainable manner. The conceptual framework for this study specifies understanding strategic management theory that reveals the foundation for improving business abilities to identify and manage change. Accordingly, Bracker (1980) identified strategic management as a theory that enabled the management of uncertainty by understanding the procedures for accomplishing goals. Strategic management can affect MFB in Nigeria positively because the directors require the ability to expand the knowledge base of strategic management in order to cope with uncertainty in the business and attain the goals of the company and nation.

\subsection{Strategic Management Best Practices}

A business interest grows with constantly environmental changes, which in turn necessitates an equal modification in the business interest to stay relevant. The business concern adaptation to these changes will require a new approach, which successful companies can offer. The business interest promoters can analyze the operations of successful companies and utilize the efficient and profitable features known for best practices to improve the business interest. Comparable successes happen to the company with similar trade of shared experiences of best practices from successful 
organizations, and the identified best practices can serve as a base for training and mentoring (Quinn \& Strategy, 2013).

Wellstein and Kieser (2011) determined that embracing successful company's best practices was the domain of consultants, but encouraged companies to apply routines and rules as mechanisms of best practices. Kandemir and Acur (2012) advocated that a successfully applied strategy of best practices required companies to realize the need to understand the new development, and have the resources to effect change. To achieve a change, Domazet et al. (2011) recommended broad business reorganization that fostered unique competitive advantages and contentment in customer expectations.

Conley and Williams (2011) explained the essence of strategic management best practice as the foundation for the MFB success and sustenance. Supporting this assertion, Karlan and Zinman (2010) signified that strategic management best practices influence improvement in microfinance banks; citing an example of an MFB with extensive outreach and allowance for credit as strategic managers with best practices. Priyadarshee, Hossain, and Arun (2010) wrote that strategic management best practices were an essential component of financial advancement strategies for MFB success.

Giving the assurance that strategic management best practice would make the low-income earners, financially excluded for centuries by the commercial bank directors in Nigeria, become gradually included in the administration and disbursement of funds. Although, MFB's still require constant supervision to harness the goal of strategic management, understanding and implementation would enhance the process. The application of strategic management best practices could improve MFB management and financial operations.

\subsection{Strategic Planning}

Strategic Planning is a well-known and documented concept that most companies make use of in one form or another to institute best practices. The benefits of strategic planning might be enormous, but not every company practices the strategic planning process (Banks, 2013). Strategic planning supports resource control allocation of time and personnel with a decision-making mechanism. Highlighted below are the features, benefits, and recommendations for the implementation of strategic planning in MFB.

\subsubsection{The features of strategic planning}

Planning usually is a preparation for the future implementation of an objective. Involving the documentation of estimates, which enables the readiness of an option when required (Ansoff, Declerck, \& Hayes, 1976). Jamshidi-Navid and Arad (2010) described strategic planning as the future activities of the company, prepared by management level officers, with an emphasis on understanding the organizational business environment, internal resources, organizational goals, review of business major activities, design, implementation plans, and evaluation of results. Constantinescu et al. (2012) identified strategic planning as a demonstration of organizational procedures and resource allocation, specific to a company and the company's operations. This understanding of strategic planning describes strategic planning as an unambiguous, brief, and accessible documentation.

\subsubsection{The benefits of strategic planning}

Several scholarly works dealt with the subject of gains in strategic planning, and most agreed on what constituted strategic planning benefits in an organization. Drucker (1992) described strategic planning as an efficient tool for evaluating, comprehending, and responding to organizational concerns where estimates clearly defined the organizational environment of the competitors, the new entrant, and available resources. Kandemir and Acur (2012) indicated that all organizations face the challenge of concerns and trends affecting the business community including competition, technological growth, and governmental policies, all of which strategic planning can address. Abdalkrim (2013) specified that strategic planning enabled an organization to focus on goals with a process that involved all staff understanding the major businesses, customers, available resources, better customer service approach, and competitive advantage for the benefit of the company.

\subsubsection{Strategic planning recommendation}

Organizations similar to MFB could benefit from strategic planning if the organization preserved the organizational uniqueness in the delivery of products and services based on research and development (Lingling, 2013). Rahman, 
Wahab, Ismail, and Udin (2013) suggested that companies should identify areas of innovative development in response to competition to create an advantage for growth, against peers and inflation burdens. The innovative moves in this area by MFB will enhance the operations to serve clients better. To Constantinescu et al. (2012), strategic planning remains instrumental for having upcoming environmental measures that would forestall unforeseen challenges while evaluating external and internal conditions, which MFB must use to forestall uncertainty in the sector. Equally, Jain and Jain (2011) stipulated that universal challenges afford opportunities for banking business growth, a strategy that can support the banking industry in creating a robust fiscal environment through planning. This strategic planning concept incorporation in MFB business could serve as an opportunity for MFB in Nigeria, to surmount the challenges of uncertainty in the sector.

Having precise information about business support strategic planning, which will assist the planning process. Strategic planning principles, if adhered to, will form the basis for change management in MFB. Similarly, the communication of strategies through planning is a vital aspect of management best practices that ensure direction for the organization and employee involvement.

\subsection{Strategic Management Information System}

Microfinance banks require strategies that incorporate the objectives of technological innovations with sustainability in business to dispel uncertainty. Management information system (MIS) is another essential strategic development in business created to earn value and grow revenue. The MFB in Nigeria is yet to embrace the MIS already practiced by MFB in other nations. This review is to inspire, encourage, and lead the MFB in Nigeria to incorporate MIS into operational systems. The upcoming sections will highlight the inspiration of innovation, computerized management systems, technological innovation benefits, and challenges in Nigerian MFB.

\subsubsection{Inspiring innovation}

Inspiring innovation as a business culture is a strategic management movement that gives a business a competitive advantage by meeting customer preferences. This inspiring innovation move enables quick response to market changes, consumer expectations, and inclinations. Strategic management innovation initiates development in goods, services, and processes, as MFB requires improvement in the research, development, service delivery, and operations (Kearins \& Fryer, 2011). Businesses that have experienced technological innovations often have inspirational trained management, motivated employees, and sustain a culture of innovation (Simon, 2013). Innovation can exist in the form of little changes and development over time that makes the product or services affordable, easy to use, and meets the needs of the consumers. Drnevich and Croson (2013) expected the beneficial merging of information systems and strategic management to improve business concerns.

\subsubsection{Computerized management systems}

Microfinance banks in Nigeria will benefit from computer innovations system if the operational strategies align with MIS. The MIS will provide the necessary flexibility that will allow safe and reliable operations. This MIS can create a platform for information initiatives to thrive such as automated teller machines (ATM), short messaging services (SMS), mobile banking, biometric device usage, interactive voice response, use of credit, smart cards, and point-of-sale (POS) transactions (Das, 2013). The MFB use of these functions will enhance the operations and create easy access to the financial transaction and safety for MFB funds. Kearins and Fryer (2011) cautioned that in implementing the MIS with the added attributes, research, and development were still very important because the sector required monitoring and improvement as MIS technology advances. The possibility of having competitive advantage in business grows as MIS implementation takes centre stage in operations because the MIS will allow efficient, fast, and accurate dissemination of information between the MFB and customers (Drnevich \& Croson, 2013).

\subsubsection{Technological innovations benefits and challenges in MFB}

Technological innovations were the preserve of the commercial banks, because innovation in the banking industry is a new concept in Nigeria. The MIS installation in MFB is a recommendation to cultivate technological innovations in management to prevent and detect fraud by creating transparency in the system, which lowers transaction, and operational costs (Kim, 2013). Though director financial capacity challenges, lack of infrastructures (the absence of 
regular electricity and internet services), government policies, and knowledge gap among directors, employees, and customers to understand the MIS concept abound (Abraham \& Balogun, 2012). Nawai and Shariff (2012) encouraged technological advancement in MFB through training, investment, and research to help reduce the director concerns.

Including MIS innovations in the business of MFB is an added advantage to harness the goals of the institution to alleviate poverty and affect the social life of the people positively. The implementation of MIS in MFB will support the growth of MFB and inculcate best practices in the operations. This implementation will align the MFB in Nigeria to global standards and collaboration in banking among the microfinance and deposit banks. The MFB implementation of MIS will improve the literacy of the customers and invariably that of the poor in Nigeria, by creating social change in the polity.

\section{Summary of the Literature Review}

The literature presented in this short review offers information on the issues that concern the microfinance-banking sector of the banking industry in Nigeria. The necessity of gathering this information is to understand the situation besieging MFB and to build tools to eradicate the uncertainty in the sector through sustainable strategic management best practices (Kanayo et al., 2013; Quinn \& Strategy, 2013). To achieve this sustainable management best practices multiple sources to ascertain the extent of the uncertainty and the best process to instill these best practices in the MFB sector in Nigeria reviewed. The literature review explored the concept of banking, discussed the history, the contemporary concerns of banking, the uncertainty in the sector, and the microfinance lending models.

The sustainability value concept highlighted corporate sustainability concepts, sustainable banking, and sustainable customer behavior, to determine potential ways to strengthen the MFB sector in Nigeria. Bracker (1980) strategic management concept explored strategic management best practices, revealing insights into strategic planning and management information systems to improve MFB director performance in Nigeria. The literature review information addressed the gap in the literature about the absence of strategic management best practices for microfinance banks and attempted to recommend management best practices suitable for the MFB sector. The specific business problem to dispel uncertainty in microfinance banks sector in Nigeria informed the discussion on technological innovation for improved performance.

This abridged literature review of the microfinance-banking sector in Nigeria provides clarity of the uncertainty in the sector, which requires regular check-ups to avoid the resultant failure of MFB because this will cause a devastating effect on the economy of the country. A research study of the literature found that failure of MFB in Nigeria would lead to the increase of financially excluded persons in the country, reduction in market volume sales, reduction in employment, and failure of small and medium enterprises, which makeup the economic strength of a nation (Fishman, 2012). This review identified the major cause of the uncertainty in the MFB sector as the lack of sustainable strategic management best practices. Building on the features recommended will assist directors to offer efficient bank performance. This literature review information could in part, fill the gap identified in Nigerian MFB's resulting from the lack of strategic management best practices in the literature. This review also encouraged finding a suitable approach to sustainable strategic management best practices, which might support the eradication of the uncertainty in the MFB sector in Nigeria.

\section{References}

Abdalkrim, G. (2013). The impact of strategic planning activities on private sector organizations performance in Sudan: An empirical research. International Journal of Business \& Management, 8, 134-143. doi:10.5539/ijbm.v8n10p134

Abraham, H., \& Balogun, I. O. (2012). Contribution of microfinance to GDP in Nigeria: Is there any? International Journal of Business and Social Science, 3,167-176. Retrieved from www.ijbssnet.com

Agier, I. (2013). Microfinance and gender: Is there a glass ceiling on Loan size? World Development, 42, 165-181. doi:10.101016/ j.worlddev.2012.06.016

Akpala, P. E., \& Olawuyi, O. J. (2013). Microfinance certification programme: A study manual. Nigeria: CIBN Press Limited

Ansoff, H. I., Declerck, R. P., \& Hayes, R. L. (1976). From strategic planning to strategic management. Business \& Economics, $24,543-551$. doi:10.1002/smj.4250030310

Assuncao J. (2013). Eliminating entry barriers for the provision of banking services: Evidence from 'banking correspondents' in Brazil. Journal of Banking \& Finance, 37, 2806-2811. doi:10.1016/j.jbankfin.2013.03.016

Ault, J. K., \& Spicer, A. (2013). The institutional context of poverty: State fragility as a predictor of cross-national variation in commercial microfinance lending. Strategic Management Journal, 1, 1-41. doi.10.1002/smj.2185

Babandi, G. (2011). Microfinance institution in Nigeria outreach and sustainability: Questionnaire survey findings. International Journal of Business \& Social Science, 2, 126-129. Retrieved from www.jjbssnet.com/journals

Bahng, G. (2013). Mitigating social exclusion in microlending: A case study of wisdom microfinance institution in Ethiopia. Journal of International Development, 25(1), 31-44. doi:10.1002/jid.1848 
Banks, G. P. (2013). Exploring small-business change and strategic adaptation in an evolving economic paradigm. (Doctoral dissertation) Available from ProQuest Dissertations and Theses database (UMI No. 3597451)

Battilana, J., \& Dorado, S. (2010). Building sustainable hybrid organizations: The case of commercial microfinance organizations. Academy of Management Journal, 53, 1419-1440. doi:10.5465/amj.2010.57318391

Bhuiyan, A. B., Siwar, C., Ismail, A. G., \& Talib, B. (2011) Islamic microcredit is the way of alternative approach for eradicating poverty in Bangladesh: A review of Islami bank microcredit scheme. Australian Journal of Basic and Applied Sciences, 5, 221-230. Retrieved from http://www.ajbasweb.com

Bracker, J. (1980). The historical development of the strategic management concept. Academy of Management Review, 5, $219-224$. doi:10.5465/AMR.1980.4288731

Central Bank of Nigeria. (2011). List of financial institutions: Microfinance banks. Retrieved from http://www.cenbank.org/Supervision/ InstMF.asp?NAV=41

Central Bank of Nigeria Publication. (2011). Revised microfinance policy. Regulatory and supervision framework for Nigeria. Abuja, Nigeria: CBN Press

Conley, J. M., \& Williams, C. A. (2011). Global banks as global sustainability regulators? The equator principles. Law \& Policy, 33, 542-575. doi:10.1111/j.1467-9930.2011.00348.x

Constantinescu, M., Caescu, S., \& Ploesteanu, M. (2012). Strategic marketing planning in sports - A perspective of quality of life improvement. Annals of the University of Oradea, Economic Science Series, 21, 807-812. Retrieved from http://anale. steconomiceuoradea.ro/en/

Crittenden, V., Crittenden, W., Ferrell, L., Ferrell, O. O., \& Pinney, C. (2011). Market-oriented sustainability: A conceptual framework and propositions. Journal of the Academy of Marketing Science, 39(1), 71-85. doi:10.1007/s11747-010-0217-2

Das S. K. (2013). Social and innovative banking strategies for sustainable banking in India. International Journal of Economics, Finance, and Management, 2, 209 -223. Retrieved from http://www.sciencepublishinggroup.com/journal

Dixit, R., \& Ghosh, M. (2013). Financial inclusion for inclusive growth of India-A study of Indian states. International Journal of Business Management \& Research (IJBMR), 3(1), 147-156. Retrieved from http://www.jjmbr.org

Domazet, I., Stosic, I., \& Zubovic, J. (2011). Strategic management concept and market restructuring as a response to new challenges of the world financial crisis. Management, 61, 78-87. Retrieved from http://www.management.fon.rs/index

Dorado, S. (2013). Small groups as context for institutional entrepreneurship: An exploration of the emergence of commercial microfinance in Bolivia. Organization Studies, 34, 533-557. doi.10.1177/0170840612470225

Dragan, O. (2012). Pathways to sustainable banking management. Annals of the University of Oradea, Economic Science Series, 21, 545-550. Retrieved from http://anale.steconomiceuoradea.ro/en/

Drnevich, P. L., \& Croson, D. C. (2013). Information technology and business-level strategy: Toward an integrated theoretical perspective. MIS Quarterly, 37, 483-509. Retrieved from http://www.misq.org

Drucker, P. F. (1992). Managing in a time of great change. New York, NY: Truman Talley Books/Dutton

Elkington, J. (1997). Cannibal with forks: The triple bottom line of 21st century business. Britain, UK: Capstone

Epstein, M. J., \& Yuthas, K. (2010). Microfinance in cultures of non-repayment. Journal of Developmental Entrepreneurship, 15(1), 35-54. doi:10.1142/s1084946710001440

Esty, K. (2011). Lessons from Muhammad Yunus and the Grameen bank. Leading long-term organizational change successfully. OD Practitioner, 43(1), 24-28. Retrieved from http://www.odnetwork.org

Fajonyomi, O. S., Jegede, C. A., \& Akinlabi, B. H. (2012). Relationship between outreach and sustainability of microfinance banks in southwestern Nigeria. OIDA International Journal of Sustainable Development, 5, 51-62. Retrieved from http://papers.ssrn. com/sol3

Fishman, J. (2012). Microfinance - Is there a solution? A survey on the use of MFIs to alleviate poverty in India. Denver Journal of International Law \& Policy, 40, 588-619. Retrieved from http://djilp.org

Florin, B., \& Carmen, B. (2013). Management control systems: A review of their components and their underlying independence. Annals of the University Of Oradea, Economic Science Series, 22(1), 1424-1433. Retrieved from http://anale.steconomiceuoradea.ro/en/

Galariotis, E., Villa, C., \& Yusupov, N. (2011). Recent advances in lending to the poor with asymmetric information. Journal of Development Studies, 47, 1371-1390. doi:10.1080/00220388.2010.527956

Garmaise, M. J., \& Natividad, G. (2013). Cheap credit, lending operations, and international politics: The case of global microfinance. The Journal of Finance, 68, 1551-1576. doi:10.1111/jofi.12045

Goel, R. K., \& Hasan, I. (2011). Economy-wide corruption and bad loans in banking: International evidence. Applied Financial Economics, 21, 455-461. doi:10.1080/09603107.2010.532112

Hart, S. L. \& Milstein, M. (2005). Sustainable value. Retrieved from http://www.stuartlhart.com

Hendrickson, J. M., \& Nichols, M. W. (2011). Troubling times for the commercial banker: Exploring the recent wave of failures. Journal of Applied Finance and Banking, 1, 1-37. Retrieved from http://www.scienpress.com/Journal_focus.asp?

Idolor, J. J., \& Eriki, P. O. (2012). Financial analysis of assessment of impact of micro-financing institutions towards poverty reduction in Nigeria. Journal of Financial Management \& Analysis, 25(1), 51-60. Retrieved from http://www.worldcat.org/

Ikechukwu, A. A. (2012). Microfinance banking in Nigeria: Problems and prospects. International Journal of Finance and Accounting, 1, 106-111 doi:10.5923/j.ijfa.20120105.04

Jain, N. S., \& Jain, N. S. (2011). Indian banking: Value creation for competitive advantage in the global environment. American Journal of Economics and Business Administration, 3, 282-286. doi:10:3844/ajebasp.2011.277.281

Jamshidi-Navid, B., \& Arad, P. H. (2010). A Clear look at internal controls: Theory and concepts. Social Science Research Network, 41, 1-27. doi:10.2139/ssrn.1342048

Johnson, S., \& Arnold, S. (2012). Inclusive financial markets: Is transformation under way in Kenya? Development Policy Review, 30, 719-748. doi:10.1111/j.1467-7679.2012.00596.x

Kandemir, D., \& Acur, N. (2012). Examining proactive strategic decision-making flexibility in new product development. Journal of Product Innovation Management, 29, 608-622. doi:10.1111/j.1540-5885.2012.00928.x 
Kanayo, O., Jumare, F., \& Nancy, S. (2013). Challenges of microfinance access in Nigeria: Implications for entrepreneurship development. Mediterranean Journal of Social Sciences, 4, 611-618. doi:10.5901/mjss.2013.v4n6p611

Karlan, D., \& Zinman, J. (2010). Expanding credit access: Using randomized supply decisions to estimate the impacts. Review of Financial Studies, 23(1), 433-464. doi:10.1093/rfs/hhp092

Kearins, K., \& Fryer, M. (2011). Relating sustainability theory to practice at Auckland airport: An engaged scholarship endeavour involving students. Corporate Social Responsibility and Environmental Management Corporation, 18, 151-161. doi:10.1002/csr.270

Kim, S. (2013). General framework for management of technology evolution. Journal of High Technology Management Research, 24, $130-137$. doi:10.1016/j.hitech.2013.09.008

Klawitter, M. M., Anderson, C. L., \& Gugerty, M. K. (2013), Savings and personal discount rates in a matched savings program for low-income families. Contemporary Economic Policy, 31, 468-485. doi:10.1111/j.1465-7287.2012.00325.x

Korth, M., Stewart, R., Rooyen, C. V., \& De Wet, T. (2012). Microfinance: Development intervention or just another bank? Journal of Agrarian Change, 12, 575-586. doi:10.1111/j.1471-0366.2012.00375.x

Kurapatskie, B., \& Darnall, N. (2013). Which corporate sustainability activities are associated with greater financial payoffs? Business Strategy and the Environment, 22(1), 49-61. doi:10.1002/bse.1735

Lerpold, L. (2012). The contextualization of microfinance model: Thunderbird International Business Review, 54(1), 117-129. doi:101002/tie21444

Lingling, G. (2013). How to improve the independence innovation capacity in medium-small enterprises? Taking the case of Henan Province as an example. Journal of Applied Sciences, 13, 3426-3430. doi:10.3923/jas.2013.3426.3430

Livingston, L., Glassman, T., \& Wright, C. (2011). Using peer-to-peer student managed fund for community service. International Journal of Interdisciplinary Social Sciences, 5, 197-209. Retrieved from http:/liji.cgpublisher.com

Marr, A. (2012). Effectiveness of rural microfinance: What we know and what we need to know. Journal of Agrarian Change, 12, 555-563. doi:10.1111/j.1471-0366.2012.00373.x

McGee, S. (2012). The lived experiences of internally motivated, healthy, middle-aged women (Doctoral dissertation). Available from ProQuest Dissertations and Theses database. (UMI No. 3508434)

Mei, C., Dhaliwal, D. S., \& Neamtiu, M. (2011). Asset securitization, securitization recourse, and information uncertainty. Accounting Review, 86, 541-568. doi:10.2308/accr.00000020

Milliman, J., \& Grosskopf, J. (2011). Lessons in leadership: Operationalizing sustainability through an integrated management system. Environmental Quality Management, 20, 15-28. doi:10.1002/tqem.20296

Morali, O., \& Searcy, C. (2013). A review of sustainable supply chain management practices in Canada. Journal of Business Ethics, 117, 635658. doi:10.1007/s10551-012-1539-4

Nawai, N., \& Shariff, N. M. N. (2012). Factors affecting repayment performance in microfinance programs in Malaysia. Procedia-Social and Behavioral Sciences, 62, 806-811. doi:10.1016/j.sbspro.2012.09.136

Olsen, T. D. (2010). New actors in microfinance lending: The role of regulation and competition in Latin America. Perspectives on Global Development \& Technology, 9, 500-519. doi:10.1163/156914910X499796

Pedrosa, J., \& Do, Q. (2011). Geographic distance and credit market access in Niger. African Development Review, 23, $289-299$. doi:10.1111/j.1467-8268.2011.00287.x

Penzenstadler, B., \& Femmer, H. (2013). A generic model for sustainability with process-and product-specific instances. Proceedings of Software Engineering, Japan, 13, 3-8. doi:10.1145/2451605.2451609

Priyadarshee, A., Hossain, F., \& Arun, T. (2010). Financial inclusion and social protection: A case for India post. Competition and Change, 14, 324-42. doi:10.1179/102452910x12837703615490

Quinn, J. B., \& Strategy, E. S. (2013). Strategic outsourcing: Leveraging knowledge capabilities. Sloan Management Review, 35, 43-55. Retrieved from http://sloanreview.mit.edu

Rahardjo, H., Idrus, M. S., Hadiwidjojo, D., \& Aisjah, S. (2013). Factors that determines the success of corporate sustainability management. Journal of Management Research, 5, 1-16. doi:10.5296/jmr.v5i2.2993

Rahman, M. A., Wahab, F. A., Ismail, R., \& Udin, N. (2013). A comprehensive innovation management model for Malaysians public higher learning institutions. International Journal of Software Engineering \& Its Applications, 7(1), 45-56. Retrieved from http://www.sersc.org

Roberts, P. W. (2013). The profit orientation of microfinance institutions and effective interest rates. World Development, 41, $120-131$. doi.10.1016/jworlddev.2012.05.022

Sandberg, J. (2012). Mega-interest on microcredit: Are lenders exploiting the poor? Journal Applied Philosophy, 29, 169-185. doi:10.1111/j.14685930.2012.00560.x

Simon, D. (2013). China's innovation gap. Mechanical Engineering, 135(1), 34-39. Retrieved from https://www.asme.org

Skiera, B., Bermes, M., \& Horn, L. (2011). Customer equity sustainability ratio: A new metric for assessing a firm's future orientation. Journal of Marketing, 75, 118-131. doi:10.1509/jmkg.75.3.118

Tavanti, M. (2013). Before microfinance: The social value of microsavings in Vincentian poverty reduction. Journal of Business Ethics, 112, 697706. doi:10.1007/x10551-012-1566-1

Taylor, M. (2011). 'Freedom from poverty is not for free': Rural development and the microfinance crisis in Andhra Pradesh, India. Journal of Agrarian Change, 11, 484-504. doi:10.1111/j.1471-0366.2011.00330.x

Tiong, P. C., \& Anantharaman, R. N. (2011). Bank sustainability disclosures: A case study of MayBank. Malaysian Accounting Review, 10, 47-54. Retrieved from http://ari.uitm.edu

Weber, O. (2012). Sustainable banking: history and current developments. Social Science Research Network, 1, 2-18. doi:10.2139/ssrn.2159947

Weill, L. (2011). Does corruption hamper bank lending? Macro and micro evidence. Empirical Economics, 41(1), 25-42.doi:10. 1007/s00181-0100393-4

Wellstein, B., \& Kieser, A. (2011). Trading "best practices" - a good practice? Industrial \& Corporate Change, 20, 683-719. doi:10.1093/ icc/dtr011

Yunus, M. (2003). Banker to the poor: Micro-lending and the battle against poverty. New York: Public Affairs 